\title{
SPRAWOZDANIE Z KONFERENCJI „REFORMACJA W RZECZYPOSPOLITEJ: KULTURA, POLITYKA, GOSPODARKA", BIAŁYSTOK, 25-26 MAJA 2006 R.
}

W dniach 25 i 26 maja 2006 r. odbywała się w Instytucie Historii Uniwersytetu w Białymstoku konferencja poświecona dziejom reformacji w Rzeczypospolitej Obojga Narodów: Reformacja w Rzeczypospolitej: kultura, polityka, gospodarka. Zorganizowano ją - wobec niesłabnącego wciąż zainteresowania dziejami reformacji - w przededniu 450. rocznicy powrotu do kraju Jana Łaskiego, słynnego reformatora religijnego. Podługim pobycie za granicą bratanek prymasa pragnął zorganizować wspólnotę kalwińską w Polsce, a także rozciągnąć wpływy swej konfesji na teren Wielkiego Księstwa Litewskiego.Rocznica stała się pretekstem do spotkania historyków zajmujących sięproblematyką szeroko rozumianego ruchu reformacyjnego, a więc $\mathrm{z}$ uwzględnieniem losów również innych niż ewangelicko-reformowana wspólnot wyznaniowych.

Swoje referaty zaprezentowali przede wszystkim historycy białostockiego środowiska naukowego (Instytut Historii UwB, IPN) oraz goście z Warszawy, Torunia, a także z Wilna i Szawel.

Spotkanie otworzyło wystąpienie Alfredasa Bumblauskasa z Wilna, określające zasięg reformacji w Wielkim Księstwie Litewskim w XVI w. Następnie tematyka obrad koncentrowała się wokół zagadnień dotyczących postaw religijnych przedstawicieli rodów magnackich Wielkiego Księstwa Litewskiego (Elżbieta Bagińska - Białystok, Tolerancja czy przymus wyznaniowy? Z dziejów polityki wyznaniowej Radziwitłów birżańskich i Genutė Kirkienè - Wilno, Postawy religijne Chodkiewiczów w okresie reformacji) oraz postaw moralnych ewangelików reformowanych (Marzena Liedke - Białystok, Skandal w zborze Pańskim, czyli o moralności ewangelików litewskich $w$ świetle akt synodów prowincjonalnych Jednoty Litewskiej XVII wieku i Jarosław Wasilewski - Białystok, Dyscyplina duchowieństwa ewangelicko-reformowanego w Wielkim Księstwie Litewskim 
w świetle akt synodów Jednoty Litewskiej). Aspekty kulturalne poruszyli: Marta Piłaszewicz-Łopatecka - Białystok (Zagadnienie sztuki w dogmatyce Ulricha Zwingliego) oraz Adam Kucharski - Toruń (Postawa wobec sztuki w pismach polskich reformatorów XVI $i$ XVII wieku), a prawne Iwona Kulesza-Woroniecka - Białystok (Regulacje dotyczące zawarcia i rozwiqzzania zwiazku małżeńskiego wśród katolików i protestantów).

Problematyka polityczna pobrzmiewała w wystąpieniach Jacka Brzozowskiego - Białystok (Otwartość religijna a interes panstwa. Zygmunt I wobec religii $i$ wyznań niekatolickich w Koronie w latach 1506-1548) i Marcina Niemyskiego - Białystok (Działalność kardynała Jana Franciszka Commendoniego na rzecz umocnienia pozycji Kościoła katolickiegow Polsce $w$ pierwszym bezkrólewiu po śmierci Zygmunta Augusta).

Aspekty regionalne dziejów reformacji ukazali Józef Maroszek - Białystok (Dzieje zboru ewangelicko-reformowanego w Zabludowie) oraz Przemysław Czyżewski - Białystok (Dobra ziemskie Kościoła ewangelicko-reformowanego w powiecie grodzieńskim w końcu XVIII wieku w świetle źródel skarbowych). Piotr Guzowski (Białystok) poszukiwał myśli kapitalistycznej w działalności ewangelików reformowanych $w$ Rzeczypospolitej (W poszukiwaniu gospodarki protestanckiej. Myśl kapitalistyczna ewangelików reformowanych w Rzeczypospolitej). Dariusz Kuźmina (Warszawa) zastanawiał się: Czy szkolnictwo jezuickie odniosto sukces $w$ XVI wieku w Rzeczypospolitej?, a Marta Kuc (Warszawa) nad problemami terminologicznymi (Polemiki wyznaniowe. Problemy terminologiczne polskiej reformacji). Adam Muszyński (Białystok) zaprezentował wyniki analizy twórczości Piotra Skargi i Szymona Staropolskiego pod kątem przedstawiania heretyków (Obraz herezji $i$ heretyków w pismach Piotra Skargi i Szymona Staropolskiego), a Karol Łopatecki (Białystok) Koncepcje Boga - Pana Historii reprezentowana przez Krzysztofa Radziwitla.

Niemal wszystkie wystąpienia wywołały ożywioną dyskusję i w opinii uczestników białostockiego spotkania konferencja, mimo swej kameralności, okazała się dogodnym forum, na którym można było zaprezentować wyniki najnowszych badań nad poszczególnymi aspektami dziejów reformacji w Rzeczypospolitej. Pokazała też, jak duże zainteresowanie dzieje te budzą wśród pracowników Instytutu Historii Uniwersytetu w Białymstoku.

Elżbieta Bagińska, Piotr Guzowski, Marzena Liedke 